\title{
An Experimental Study of an Evacuated Tube Solar Collector Using the Response Surface Methodology (RSM)
}

\author{
Abdelmadjid Bensaha $^{1 *}$, Fatiha Benkouider ${ }^{2}$, SMA. Bekkouche ${ }^{1}$, Abdelkader Abdellaoui ${ }^{3}$, Toufik Chergui ${ }^{1}$, \\ Abdelwahab Benseddik \\ ${ }^{1}$ Unité de Recherche Appliquée en Energies Renouvelables (URAER), Centre de Développement des Energies Renouvelables, \\ CDER, 47133, Ghardaïa, Algérie. \\ ${ }^{2}$ Laboratoire des Télécommunications, Signaux et Systèmes (LTSS), Université Amar Telidji de Laghouat, BP G37, route de \\ Ghardaia, Laghouat, Algérie \\ ${ }^{3}$ Université Paris Est-Créteil, Université paris XII, France
}

Corresponding Author Email: bensaha.madjid@gmail.com

https://doi.org/10.18280/mmc_b.882-414

Received: 26 June 2019

Accepted: 6 November 2019

\section{Keywords:}

experimental study, evacuated tube solar collector, response surface methodology

\begin{abstract}
The purpose of this study is to investigate experimentally the performance of a solar hot water system with evacuated tube solar collector to obtain optimum process parameters by user-specified design. In these study parameters as solar radiation and fluid flow are optimized with the consideration of responses as outlet fluid temperature and bottom water temperature using the Response Surface Methodology (RSM). As a result, the optimal independent variables in the determined intervals are as follows: solar radiation is $850 \mathrm{w} / \mathrm{m} 2$ and fluid flow is $1,36641 \mathrm{l} / \mathrm{min}$; under these favorable conditions, the outlet fluid temperature can reach a maximum value of $75.9954^{\circ} \mathrm{C}$ whereas the bottom water temperature in the storage tank may attain a maximum value of $65.1443{ }^{\circ} \mathrm{C}$. It was found from the experimental design and ANOVA using the STATGRAPHICS Centurion (VERSION 18) program, that the solar radiation is the major parameter that influences of a solar hot water system performance.
\end{abstract}

\section{INTRODUCTION}

A solar water heating system is the conversion of sunlight into heat for water heating using a solar thermal collector such as flat plate systems, evacuated tube systems and thermosyphon systems. These systems are widely used in residential sector and some industrial applications.

In this study, we are interested in a heat pipe evacuated tube collector (HP-ETC) made up of a heat U-pipe inside a vacuum tube. The vacuum envelope reduces convection and conduction losses, so the collectors can operate at higher temperatures than flat plate collectors or thermosyphon collectors. The product IMEXSol 200L is intended for the production of domestic hot water using solar energy by heating a heat transfer fluid in a closed circuit. Vacuum tubes absorb solar radiation to turn it into heat. The heat is transported by a heat transfer fluid through the U-pipe in the vacuum tubes to a 200-liter storage tank through a coil finally to transfer heat collected by the solar collector to water inside the storage tank.

Hayek et al. [1] The authors investigated and compared the overall performance of two types of solar collectors (water in glass collector and heat pipe evacuated tube collector) under Eastern Mediterranean climatic conditions. They concluded that the heat pipe evacuated tube collector performs better than water in glass collector. In another work, Ayompe and Duffy [2] presented an analysis of a solar water heater system with a $3 \mathrm{~m}^{2}$ heat pipe evacuated tube collector using data from a field trial in Dublin, Ireland.

Azimi et al. [3] studied the performance of evacuated tube solar collector in different climatic conditions in Iran using
TRNSYS 16 software; they also improved instantaneous sensor yield using genetic algorithm in MATLAB software.

Laurence et al. [4] evaluated the performance of an evacuated tube solar hot water system installed on a domestic house of 5 persons in Dublin, they found that the system produced $1216 \mathrm{~kW}$ h of useful heating energy with a system efficiency of $62.8 \%$.

Kabeel et al. [5] designed a modified coaxial heat pipes to improve the thermal performance of evacuated tube solar collector, the results show that the thermal efficiency can reach a maximum value of $67 \%$ at a mass flow rate of $0.009 \mathrm{~kg} / \mathrm{s}$.

Elsheniti et al. [6] presented the thermal performance of a heat-pipe evacuated-tube solar collector at a high inlet temperature by predicting the thermal efficiency as a function of operating parameters such as fluid flow, inlet temperature and number of evacuated tubes.

Evaluation of the overall performance of solar collectors is usually carried out experimentally using proven procedures according to international standards [7-10] and many correlations have been developed for the purpose of predicting the overall efficiency under various climatic conditions.

The response surface methodology (RSM) is a widely used mathematical and statistical method for modeling and analyzing a process in which the response of interest is affected by various variables [11] and the objective of this method is to optimize the response [12]. The parameters that affect the process are called dependent variables, while the responses are called dependent variables [13].

The RSM method was used in many fields such as optimizing the performance of thermal efficiency of the 
evacuated tube solar collector [14], optimizing parabolic mirror position in a solar cooker [15,16], optimizing extraction of plant materials [17], Optimization of hydrogen production [18] and the parameters of solar Drying [19, 20].

Our literature review shows that no one has used the response surface methodology in the domain of solar domestic hot water system, especially when combining the operating parameters to optimize the system. Accordingly, the present study focused on modeling the effect of the solar radiation and fluid flow (as independent variables) on the outlet fluid temperature and bottom water temperature in the vertical storage tank (as dependent variables) in a process of domestic hot water. The modeling was based on the Response Surfaces Methodology. The experiments were designed according to the user-specified design plan with two factors, each at five different levels.

\section{MATERIALS AND METHODS}

\subsection{Experimental of a Solar Hot Water System}

An experimental set-up was designed and installed on the workshop rooftop in the Applied Research Unit in Renewable Energies in Ghardaia region- Algeria. Figure 1 shows all the kit components of the product IMEXSol200L with a solar collector made up of 12 evacuated tubes and a vertical storage tank. The experimental set-up is a closed loop circuit with the required components and measurement tools as sketched in figure 1.

A vacuum solar collector consists of a series of 12 transparent glass tubes, the length of the tubes is $1.73 \mathrm{~m}$ and their diameter is $4 \mathrm{~cm}$. In each tube there is an absorber for capturing solar radiation and a U-pipe type heat exchanger to allow the transfer of thermal energy. Vacuum sensors can reach high temperatures $\left(150^{\circ} \mathrm{C}\right)$. The vacuum created inside the tubes makes it possible to reduce significantly the losses during rise in temperature.

The solar collector consists of 12 U-pipe collectors filled with a heat transfer liquid, which transports the calories captured by the solar collector to the hot water storage tank; this transport is carried out via a forced pipe (the solar pump). The solar collector is oriented towards the South and inclined by $32^{\circ}$.

The regulator of RESOL type is an electronic device that controls the flow of heat transfer fluid through a solar pump that circulates the fluid within the closed circuit between the solar collector and the tank. The role of this control system is the adjustment and the control of the solar station $\left(\mathrm{R}_{1}\right)$ and electric auxiliary station $\left(\mathrm{R}_{2}\right)$. In this work, the operation of $\mathrm{R}_{2}$ was cancelled.

The storage tank is equipped with several automatic control and protection means such as a thermostatic control, protection for high and medium temperatures and pressure protection ( $\mathrm{P}$ / $\mathrm{T}$ valve and check valve), equipped with a supplementary electric heating element (auxiliary heater $\mathrm{R}_{2}$ ) for safety. The storage tank transmits the calories provided by the heat transfer liquid to the water (through the exchanger located at the bottom of the tank).

The ImexSol 200L system consists of four probes: thermistors $S_{1}$ and $S 4$ which measure the temperature of the heat transfer liquid at the inlet and outlet of the solar collector respectively; $S_{2}$ and $S 3$ which measure the water temperature in the lower and upper level of the tank respectively.
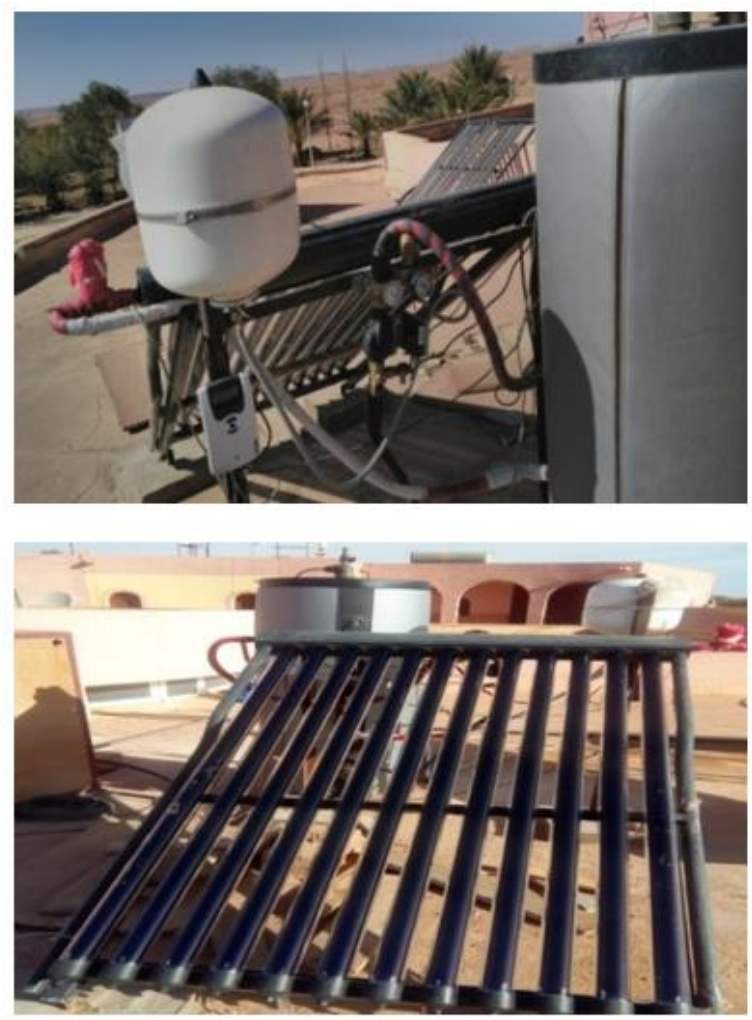

Figure 1. The product IMEXSol 200L installed in Ghardaïa region

The regulator calculates the temperature difference between thermistors $\mathrm{S}_{1}$ and $\mathrm{S}_{2}$, if this difference is greater than $+1^{\circ} \mathrm{C}$, the solar pump $\left(\mathrm{R}_{1}\right)$ is switched on; by contrast, the solar pump is switched off when the outlet fluid temperature is higher than the bottom water temperature by the predefined deactivation value of $0.5^{\circ} \mathrm{C}$ (DTF).

\subsection{Method adapted for statistical analysis}

The response surface methodology (RSM) has been proven to be a powerful tool for determining the effects of each factor and the interactions among them, thereby allowing for effective process optimization [21]. The response surface procedures involve experimental strategy, mathematical methods, and statistical inference, which, when combined, enable users to make an efficient empirical exploration of the system in which they are interested [22].

RSM can be applied to any system that has the following key elements: (1) a criterion of effectiveness, measurable on a continuous scale (extraction time), and (2) quantifiable independent variables (both controllable and uncontrollable) that affect the system's performance (such as the extraction process, solvent, and drying method). Given these conditions, RSM offers techniques for finding the optimum response of the system in an efficient manner [22]. The major advantage of RSM is that the amount of data needed for evaluation, analysis and optimization significantly reduces the number of experiments required. RSM is a faster and more economical method for collecting research results than the classic onevariable at a time or full-factor experimentation [16]

The STATGRAPHICS Centurion software (VERSION 18) has been used for this purpose. RSM generates the table for the experimental design plan specified by the user. This experimental strategy has been widely used in production / 
process development.

To study the effect of the operational parameters of solar water heating system, two operating parameters were favored and selected: solar radiation (between 250 and $850 \mathrm{w} / \mathrm{m}^{2}$ ) and heat transfer fluid flow (between 0.6 and $31 / \mathrm{min}$ ). After choosing the operating parameters that are the most influential and because of a large possible range of variation of each parameter, it was convenient to carry out a statistical study to identify, at the least cost of experimentation, the domain of exploitation of the parameters. Thus, during the present study, the surface response method was adopted; it is a user-specified design plan with two factors, each with five different levels.

The experimental design is presented in Table 1. The aim is to obtain samples adapted to the 25-point experimental design given in Table 2. The relationship between the independent variables, solar radiation $\left(\mathrm{x}_{1}\right)$, and the flow of the heat transfer fluid $\left(\mathrm{x}_{2}\right)$ is expressed mathematically in the form of a polynomial model, which gave the following two responses: the outlet fluid temperature $\mathrm{Y}_{1}$ and the bottom water temperature $\mathrm{Y}_{2}$ according to these variables. A second-order polynomial equation is presented in the following general form:

$$
Y_{k}=a_{0}+\sum_{i=1}^{2} a_{i} x_{i}+\sum_{i=1}^{2} a_{i} x_{i}^{2}+\sum_{i=1}^{2} \sum_{j=1}^{2} a_{i j} x_{i} x_{j}
$$

Table 1. The levels of the variables utilized in this study for the user-specified design

\begin{tabular}{cccccc}
\hline variables & \multicolumn{5}{c}{ Levels of the user-specified design } \\
\hline $\mathrm{x}_{1}\left(\mathrm{w} / \mathrm{m}^{2}\right)$ & 250 & 400 & 550 & 700 & 850 \\
\hline $\mathrm{x} 2(1 / \mathrm{min})$ & 0.6 & 1.2 & 1.8 & 2.4 & 3 \\
\hline
\end{tabular}

Table 2. Conditions and experimental design results based on the plan of the user-specified design at five levels

\begin{tabular}{|c|c|c|c|c|c|c|}
\hline \multirow{3}{*}{$\mathbf{N}$} & \multicolumn{2}{|c|}{ Factors values } & \multicolumn{4}{|c|}{ Responses values } \\
\hline & & \multicolumn{2}{|c|}{$\mathbf{Y}_{1}\left({ }^{\circ} \mathbf{C}\right)$} & \multicolumn{2}{|c|}{$\mathbf{Y}_{2}\left({ }^{\circ} \mathbf{C}\right)$} \\
\hline & $\mathbf{x} 1\left(w / m^{2}\right)$ & $\mathbf{x} 2(l / m i n)$ & $\begin{array}{c}\text { Observed } \\
\text { values }\end{array}$ & $\begin{array}{c}\text { Predicted } \\
\text { values }\end{array}$ & $\begin{array}{c}\text { Observed } \\
\text { values }\end{array}$ & $\begin{array}{c}\text { Predicted } \\
\text { values }\end{array}$ \\
\hline 1 & 250 & 0,6 & 46,5 & 47,6914 & 38,8 & 38,8257 \\
\hline 2 & 400 & 0,6 & 57,2 & 56,2931 & 46,4 & 45,4051 \\
\hline 3 & 550 & 0,6 & 65,5 & 63,8777 & 52,0 & 51,6503 \\
\hline 4 & 700 & 0,6 & 70,8 & 70,4451 & 57,8 & 57,5611 \\
\hline 5 & 850 & 0,6 & 75,7 & 75,9954 & 62,7 & 63,1377 \\
\hline 6 & 250 & 1,2 & 46,0 & 46,5766 & 41,3 & 42,3217 \\
\hline 7 & 400 & 1,2 & 53,9 & 54,5183 & 47,1 & 48,5051 \\
\hline 8 & 550 & 1,2 & 60,7 & 61,4429 & 52,9 & 54,3543 \\
\hline 9 & 700 & 1,2 & 66,4 & 67,3503 & 58,4 & 59,8691 \\
\hline 10 & 850 & 1,2 & 70,9 & 72,2406 & 63,5 & 65,0497 \\
\hline 11 & 250 & 1,8 & 46,6 & 45,4103 & 44,9 & 43,3577 \\
\hline 12 & 400 & 1,8 & 53,4 & 52,692 & 51,5 & 49,1451 \\
\hline 13 & 550 & 1,8 & 59,9 & 58,9566 & 57,8 & 54,5983 \\
\hline 14 & 700 & 1,8 & 64,9 & 64,204 & 63,3 & 59,7171 \\
\hline 15 & 850 & 1,8 & 69,2 & 68,4343 & 67,8 & 64,5017 \\
\hline 16 & 250 & 2,4 & 44,2 & 44,1926 & 40,4 & 41,9337 \\
\hline 17 & 400 & 2,4 & 49,0 & 50,8143 & 43,8 & 47,3251 \\
\hline 18 & 550 & 2,4 & 56,4 & 56,4189 & 49,8 & 52,3823 \\
\hline 19 & 700 & 2,4 & 61,1 & 61,0063 & 55,3 & 57,1051 \\
\hline 20 & 850 & 2,4 & 64,8 & 64,5766 & 59,2 & 61,4937 \\
\hline 21 & 250 & 3 & 44,3 & 42,9234 & 40,0 & 38,0497 \\
\hline 22 & 400 & 3 & 47,6 & 48,8851 & 42,7 & 43,0451 \\
\hline 23 & 550 & 3 & 53,5 & 53,8297 & 48,5 & 47,7063 \\
\hline 24 & 700 & 3 & 57,7 & 57,7571 & 53,0 & 52,0331 \\
\hline 25 & 850 & 3 & 61,0 & 60,6674 & 56,2 & 56,0257 \\
\hline
\end{tabular}

\section{RESULTS AND DISCUSSIONS}

\subsection{Responses surface analysis and interpretation}

The experimental data were employed to calculate the coefficients of the quadratic equation. Table 3 summarizes the results concerning the analysis of the variance (ANOVA) for the responses and the coefficients of the mathematical models.

The coefficient of determination $\mathrm{R}_{2}$ represents the proportion of variation of the response attributed to the model rather than the random error. It has been suggested that a good fit of models should have $\mathrm{R}_{2}$ not less than $90 \%$. When $\mathrm{R}_{2}$ is close to unity, the empirical models are adapted to fit the experimental data.

Based on these results, an empirical relationship between system responses and independent variables has been established for domestic hot water and then expressed by second-order polynomial equations as follows:

$$
\begin{gathered}
Y_{1}=31.06+0.08 x_{1}+0.1 x_{2}-0.071 x_{1}^{2} \\
-0.0073 x_{1} x_{2} \\
Y_{2}=20.5+0.05 x_{1}+13.08 x_{2}-0.0000074 x_{1}^{2} \\
-3.42 x_{2}^{2}-0.0044 x_{1} x_{2}
\end{gathered}
$$

The response surface analysis (RSA) of the data in Table 3 shows that the relationship between the responses and the independent variables (solar radiation and fluid flow) is quadratic, with a good regression coefficient $(99.0237 \%$ for $\left(\mathrm{Y}_{1}, \mathrm{R}_{2}\right)$ and $94.6654 \%$ for $\left(\mathrm{Y}_{2}, \mathrm{R}_{2}\right)$. This indicates that there was good agreement between the experimental data and the two predicted responses. 
The results show that the models used in this study were able to identify the optimal operating condition of this solar system dedicated to heating sanitary water. Figure 2 describes the correlation between the value of the observed response and that of the predicted response by the mathematical model; it shows a good correlation between the responses of the system obtained experimentally and those predicted by the mathematical models proposed from equations 2 and 3.

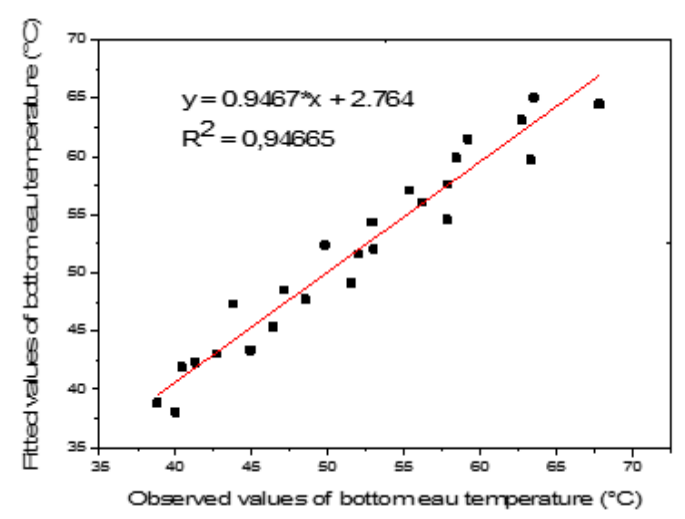

(a)

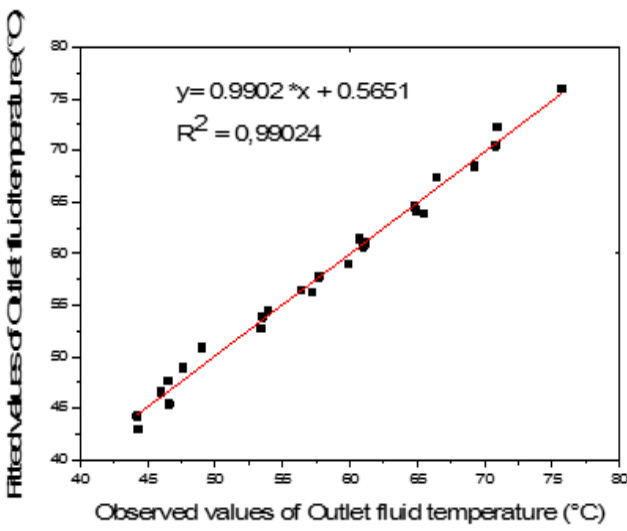

(b)

Figure 2. Linear correlation between calculated and measured system responses

Table 3. Analysis of variance (ANOVA), linear, interaction and quadratic terms for each response variable and the prediction model coefficients

\begin{tabular}{|c|c|c|c|c|c|c|c|}
\hline & Source & Coefficients & $\begin{array}{c}\text { Sum of } \\
\text { Squares }\end{array}$ & DDL & $\begin{array}{l}\text { Mean of } \\
\text { squares }\end{array}$ & F-value & $\begin{array}{l}\text { p-Value } \\
\text { prob }>F\end{array}$ \\
\hline \multirow{22}{*}{ 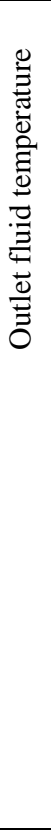 } & $\mathrm{x}_{1}$ & 0,0764368 & 1656,6 & 1 & 1656,6 & 1569,75 & 0,0000 \\
\hline & $\mathrm{x}_{2}$ & 0,10381 & 315,5 & 1 & 315,5 & 298,97 & 0,0000 \\
\hline & $\mathrm{x}_{1}{ }^{2}$ & $-0,0000226032$ & 18,105 & 1 & 18,105 & 17,16 & 0,0006 \\
\hline & $\mathrm{x} 2^{2}$ & $-0,0714286$ & 0,0463 & 1 & 0,0463 & 0,04 & 0,8363 \\
\hline & $\mathrm{x}_{1} \mathrm{X}_{2}$ & $-0,00733333$ & 43,56 & 1 & 43,56 & 41,28 & 0,0000 \\
\hline & Residual & & 20,051 & 19 & 1,05531 & - & - \\
\hline & $\mathrm{R}_{2}(\%)$ & 99,0237 & & & & & \\
\hline & Adj- $R_{2}$ (adjusted for d.f.) & $98,7668 \%$ & & & & & \\
\hline & the standard deviation of the residue & 1,02728 & & & & & \\
\hline & Mean Sequare Error & 0,737646 & & & & & \\
\hline & Durbin-Watson test & 1,53068 & & & & & \\
\hline & $\mathrm{x}_{1}$ & 0,0513314 & 1397,1 & 1 & 1397,1 & 300,18 & 0,0000 \\
\hline & $\mathrm{x}_{2}$ & 13,0767 & 48,6 & 1 & 48,6 & 10,44 & 0,0044 \\
\hline & $\mathrm{x}_{1}{ }^{2}$ & $-0,00000742857$ & 1,9556 & 1 & 1,9556 & 0,42 & 0,5246 \\
\hline & $\mathrm{x}_{2}^{2}$ & $-3,41667$ & 105,90 & 1 & 105,90 & 22,75 & 0,0001 \\
\hline & $\mathrm{x}_{1} \mathrm{x}_{2}$ & $-0,0044$ & 15,681 & 1 & 15,681 & 3,37 & 0,0821 \\
\hline & Residual & & 88,430 & 19 & 4,6542 & - & - \\
\hline & $\mathrm{R}_{2}(\%)$ & 94,6654 & & & & & \\
\hline & Adj-R ${ }_{2}$ (adjusted for d.f.) (\%) & 93,2616 & & & & & \\
\hline & $\begin{array}{l}\text { The standard deviation of the } \\
\text { residue }\end{array}$ & 2,15736 & & & & & \\
\hline & Mean Sequare Error & 1,55589 & & & & & \\
\hline & Durbin-Watson test & 0,767507 & & & & & \\
\hline
\end{tabular}

(a)

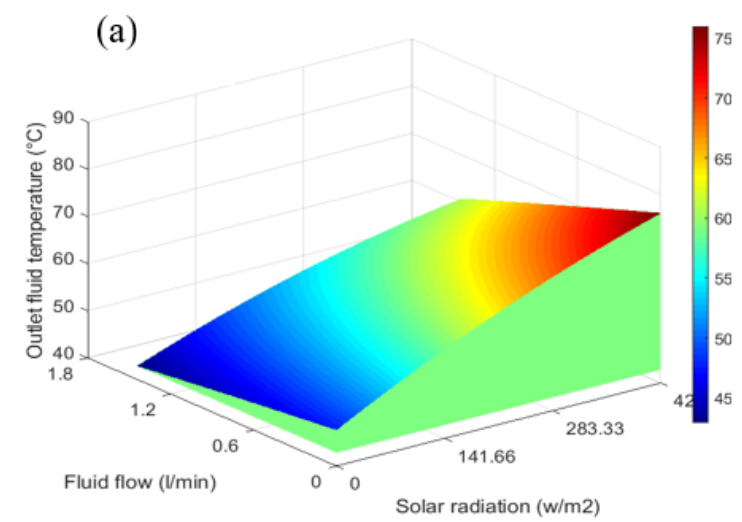

(b)

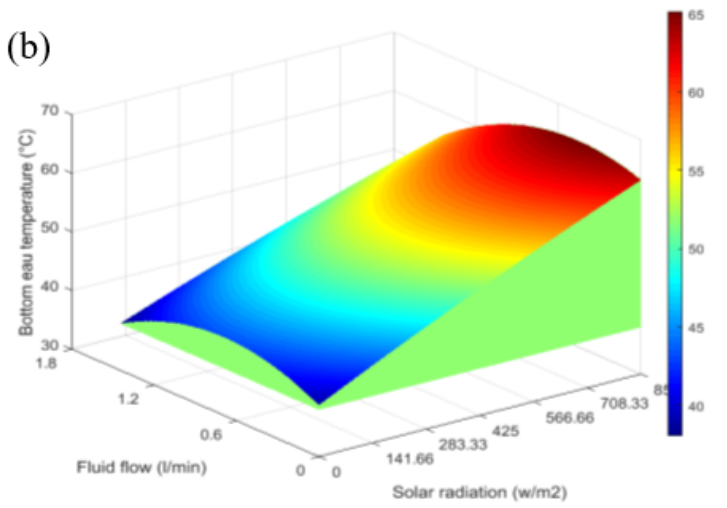


(c)

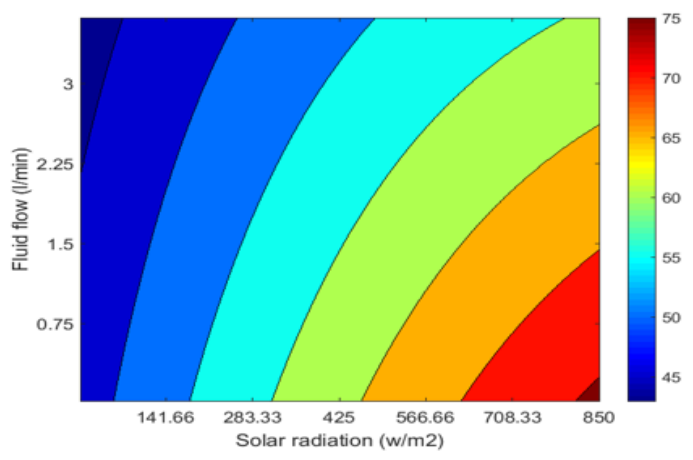

(d)

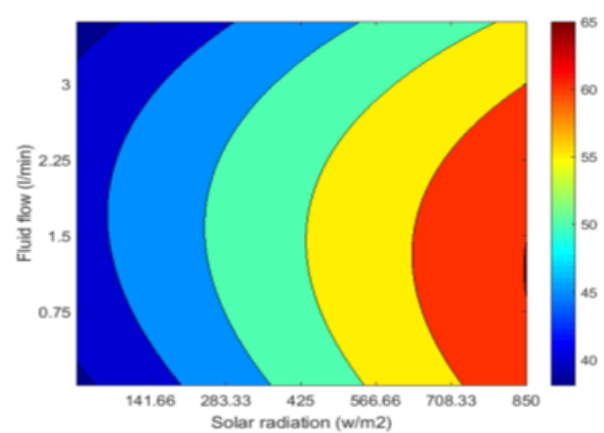

Figure 3. Response surfaces (a, b) and isopleth curves (c,d)

However, it is clear that the experimental results of the responses $\mathrm{Y} 1$ and $\mathrm{Y} 2$ and the predicted values obtained using equations 2 and 3 are not significantly different (Figure 2).

On the other hand, from equations 2 and 3, we can obtain the 3D response surfaces and the isopleth curves shown in Figures (3) (a-b) and (3) (c-d) respectively. These figures illustrate the effect of solar radiation (x1) and the fluid flow (x2) on the outlet fluid temperature in the solar collector and the bottom water temperature in the storage tank (Y1 and Y2).

We can see from Figure 3 that $\mathrm{Y} 1$ is proportional to $\mathrm{x} 1$ and inversely proportional to $\mathrm{x} 2$. However, $\mathrm{Y} 2$ is proportional to $\mathrm{x} 1$ and $\mathrm{x} 2$ around the mean level. As can be seen in figure 3 (a and c) that for lower or higher $\mathrm{x} 2$ values, both responses increase as solar radiation increases.

\subsection{Optimization of parameters}

According to the above analysis, solar radiation is the most important variable, so that the optimization of solar radiation always corresponds to the maximum value of the interval. Optimization of the variables is given in Table 4. So, it can be seen from this table that the optimal independent variables are as follows: the solar radiation is $850 \mathrm{w} / \mathrm{m}^{2}$ and the fluid flow is $1.36641 \mathrm{l} / \mathrm{min}$. Under these appropriate conditions, the temperature of the oulet fluid temperature can reach amaximum value of $75.9954{ }^{\circ} \mathrm{C}$ while the bottom water temperature in the vertical storage tank can reach the maximum value of $65.1443{ }^{\circ} \mathrm{C}$.

Table 4. The levels of the variables used in this study for user-specified design in the response surface methodology

\begin{tabular}{ccccc}
\hline Levels & $\begin{array}{c}\text { Optimal values of independent variables } \\
\text { Solar radiation } \\
\left(\mathbf{w} / \mathbf{m}^{\mathbf{2}}\right)\end{array}$ & $\begin{array}{c}\text { Fluid flow } \\
(\mathbf{l} / \mathbf{m i n})\end{array}$ & $\begin{array}{c}\text { Outlet fluid } \\
\text { temperature }\left({ }^{\circ} \mathbf{C}\right)\end{array}$ & $\begin{array}{c}\text { Besponses } \\
\text { Bottom water } \\
\text { temperature }\left({ }^{\circ} \mathbf{C}\right)\end{array}$ \\
\hline Low & $\boldsymbol{x}_{\boldsymbol{I}}$ & $\boldsymbol{x}_{\boldsymbol{2}}$ & $\boldsymbol{Y}_{\boldsymbol{I}}$ & $\boldsymbol{Y}_{\boldsymbol{I}}$ \\
High & 250 & 0.6 & 46,5 & 38,8 \\
Optimum & 850 & 3 & 61 & 56,2 \\
\hline
\end{tabular}

\section{CONCLUSION}

An experimental set-up was installed under optimal design conditions of the response surface methodology to investigate the influence of the above parameters on domestic solar hot water. From the quadratic models of the response surfaces, it was found that the outlet fluid temperature and the bottom water temperature in the storage tank were significantly affected by solar radiation. The optimized parameters are presented as follows: Solar radiation is $850 \mathrm{w} / \mathrm{m}^{2}$, and fluid flow is $1.36641 \mathrm{l} / \mathrm{min}$, under these optimal conditions, outlet fluid temperature is $75.9954{ }^{\circ} \mathrm{C}$ while the bottom water temperature is $65.1443{ }^{\circ} \mathrm{C}$.

\section{ACKNOWLEDGMENT}

This work was performed in the Unité de Recherche Appliquée en Energies Renouvelables (URAER), Centre de Développement des Energies Renouvelables, CDER, Ghardaïa, Algérie.

The authors would like to thank the personelle for their support in materials as well as all the collaborators of this work.

\section{REFERENCES}

[1] Hayek, M., Assaf, J., Lteif, W. (2011). Experimental investigation of the performance of evacuated tube solar collectors under Eastern Mediterranean climatic conditions. Energy Procedia, 6: 618-626. https://doi.org/10.1016/j.egypro.2011.05.071

[2] Ayompe, L.M., Duffy, A. (2013). Thermal performance analysis of a solar water heating system with heat pipe evacuated tube collector using data from a field trial. Solar Energy, 90: 17-28.

[3] Azimi, M., Mirjavadi, S.S., Karim, M.A. (2016). Simulation and optimization of vacuum tube solar collector water heating system in Iran. Journal of Science and Engineering, 7: 1-19.

[4] Gill, L., Mahon, J.M., Ryan, K. (2016). The performance of an evacuated tube solar hot water system in a domestic house throughout a year in a northern maritime climate (Dublin). Solar Energy, 137: 261-272. https://doi.org/10.1016/j.solener.2016.07.052

[5] Kabeel, A.E., Dawood, M.K., Shehata, A.I. (2017). Augmentation of thermal efficiency of the glass evacuated solar tube collector with coaxial heat pipe with 
different refrigerants and filling ratio. Energy Conversion and Management, 138: 286-298. https://doi.org/10.1016/j.enconman.2017.01.048

[6] Elsheniti, M., Kotb, A., Elsamni, O. (2019). Thermal performance of a heat-pipe evacuated-tube solar collector at high inlet temperatures. Applied Thermal Engineering, 154: 315-325. 10.1016/j.applthermaleng.2019.03.106

[7] Gowda, N., Gowda, B.P.B., Chandrashekar, R., Ugrasen, G., Keshavamurthy, R. (2014). Experimental Investigation of Evacuated Tube Solar Collector with Annular Heat Exchanger. Applied Mechanics and Materials, 592-594, 2355-2359. https://doi.org/10.4028/www.scientific.net/amm.592594.2355

[8] ASHRAE (2010). Methods of Testing to Determine the Thermal Performance of Solar Collectors. ASHRAE 93.

[9] Zambolin, E., Del Col, D. (2010), Experimental analysis of thermal performance of flat plate and evacuated tube solar collectors in stationary standard and daily conditions, Solar Energy, 84: 1382-1396.

[10] Kong., W., Wang, Z., Fan, J., Bengt, P., Chen, Z. ,Perers, B., Furbo, S., Andersen, E. (1912). Investigation of Thermal Performance of Flat Plate and Evacuated Tubular Solar Collectors According to a New Dynamic Test Method. https://doi.org/10.1016/j.egypro.2012.11.019

[11] Braimah, M.N., Anozie, A.N., Odejobi, O.J. (2016). Utilization of Response sUrface Methodology (RSM) in the Optimization of Crude Oil Refinery Process, New Port-Harcourt Refinery, Nigeria. Journal of Engineering Science and Technology, 3, 4361-4369.

[12] Sarafraz, M.M., Tlili, I., Tian, Z., Bakouri, M., Safaei, M.R. (2019). Smart optimization of a thermosyphon heat pipe for an evacuated tube solar collector using response surface methodology (RSM). Physica A: Statistical Mechanics and Its Applications, 534, 122146.

[13] Montgomery, D.C. (2005). Design and Analysis of Experiments: Response Surface Method and Designs. New Jersey: John Wiley and Sons, Inc.

[14] Koç, B., Kaymak-Ertekin, F. (2010). Response surface methodology and food processing applications. GIDAJournal of Food, 35(1): 63-70.

[15] Zamani, H., Moghiman, M., Kianifar, A. (2015). Optimization of the parabolic mirror position in a solar cooker using the response surface method (RSM).
Renewable Energy, $\quad 81 \quad$ : $\quad$ 753-759. https://doi.org/10.1016/j.renene.2015.03.064

[16] Muthusivagami, R.M., Velraj, R., Sethumadhavan, R. (2010). Solar cookers with and without thermal storage - a review. Renewable and Sustainable Energy Reviews, 14(2): 691-701.

[17] Aydar, A.Y. (2018). Utilization of response surface methodology in optimization of extraction of plant materials. Statistical Approaches with Emphasis on Design of Experiments Applied to Chemical Processes. https://doi.org/10.5772/intechopen.73690

[18] Bamidele, V.A., Ghazali, A.A., Yassin, M.Y.M., Abdullah, S. (2018). Optimization of hydrogen production by photocatalytic steam methane reforming over lanthanum modified Titanium (IV) oxide using response surface methodology. International journal of hydrogen energy, 1-11. https://doi.org/10.1016/j.ijhydene.2018.06.185

[19] Adeodu, O., Daniyan, A., Ilesanmi, A. (2018). Development and Optimisation of Drying Parameters for Low-Cost Hybrid Solar Dryer Using Response Surface Method. Journal of Sustainable Bioenergy Systems, 8: 23-35. https://doi.org/10.4236/jsbs.2018.82002

[20] Ikranga, E.G., Umani, K.C. (2019). Optimization of process conditions for drying of catfish (Clarias gariepinus) using Response Surface Methodology (RSM). Food Science and Human Wellness, 8: 46-52. https://doi.org/10.1016/j.fshw.2019.01.002

[21] Bas, D., Boyaci, I.H. (2007). Modelling and optimization. Usability of response surface methodology. Journal of Food Engineering, 78: 836-845. https://doi.org/10.1016/j.jfoodeng.2005.11.024

[22] Krishnaiah, D., Bono, A., Sarbatly, R., Nithyanandam, R., Anisuzzaman, S.M. (2015). Optimisation of spray drying operating conditions of Morindacitrifolia L. fruit extract using response surface methodology. Journal of King Saud University - Engineering Sciences, 27: 26-36. https://doi.org/10.1016/j.jksues.2012.10.00

\section{NOMENCLATURE}

$\begin{array}{ll}\mathbf{x}_{1} & \text { Solar radiation }\left(\mathbf{w} / \mathbf{m}^{2}\right) \\ \mathrm{X}_{2} & \text { heat transfer fluid }(1 / \mathrm{min}) \\ \mathrm{Y}_{1} & \text { Outlet fluid temperature }\left({ }^{\circ} \mathrm{C}\right) \\ \mathrm{Y}_{2} & \text { Bottom water temperature }\left({ }^{\circ} \mathrm{C}\right)\end{array}$

